\title{
Energetics of Greengram (Vigna radiata L.) Production as Affected by Residual Effect of Rice Establishment Methods and Nutrient Management Practices in Rice-Greengram Cropping System
}

\author{
Tushar Ranjan Mohanty ${ }^{1}$, Pravat Kumar Roul ${ }^{2}$ and Swapan Kumar Maity ${ }^{3}$ \\ ${ }^{1}$ (All India Coordinated Research Project on MULLaRP, Orissa University of Agriculture \& Technology, \\ Keonjhar (Odisha), India) \\ ${ }^{2}$ (Director, Polytechnique, Orissa University of Agriculture \& Technology, Bhubaneswar, Odisha, India) \\ ${ }^{3}$ (Department of ASEPAN, Pallisiksha Bhavana, Visva-Bharati University, Santiniketan, West Bengal, India)
}

\begin{abstract}
Field experiments were conducted. to study the residual effect of three rice establishment methods (SRI, drum seeding and conventional transplanting) and three nutrient management practices [RDF (80:40:40 N: P2O5: K2O kg ha-1), 50\% R.D.F. $+50 \%$ R.D.F. through organic sources (based on nitrogen requirement) i.e. INM and $100 \% R D F$ through organic management $(O M)]$ and direct effect of three nutrient management practices viz. RDF (20:40:40 N: P2O5: K2O kg hal $), 50 \% \mathrm{RDF}+$ Biofertlizer (BF) and no fertilizer on energetics of greengram in a rice-greengram cropping system during rabi seasons of 2009-10 and 2010-11. The design was split plot in kharif and split-split plot in rabi with treatments replicated thrice. Methods of rice establishment did not influence the yield and energetics of subsequent greengram. Residual effect of sole organic nutrient management being at par with integrated nutrient management came out to be the best in terms of yield and energy indices like energy output, energy productivity and energy ratio. $50 \% R D F+B F$ application to greengram recorded the highest seed yield $\left(930 \mathrm{~kg} \mathrm{ha}^{-1}\right)$. This treatment also recorded the highest energy output $\left(55.7 \mathrm{MJx10^{3 }}\right)$, energy productivity $\left(247.3 \mathrm{Kg} / \mathrm{MJ} \times 10^{3}\right)$ and energy ratio(14.81).
\end{abstract}

Keywords: bio-fertilizer, crop establishment, greengram, nutrient management, energetics

\section{Introduction}

India is the highest producer as well as consumer of pulses in the world and contributes $25.5 \%$ of total global pulse production (GOI, 2013). Greengram (Vigna radiata L.) is the third important pulse crop of India grown in nearly 8 per cent of the total pulse area of the country. In Odisha, greengram is cultivated in an area of 0.836 million ha with a production of 0.362 million tonnes and productivity of only $434 \mathrm{~kg} \mathrm{ha}^{-1}$ (OAS, 201011). It is grown mainly in rabi and summer seasons after harvest of rice. Rice-greengram cropping system is the most important cropping system in vogue in North Central Plateau Zone of Odisha.

Method of stand establishment is one cultural practice which influences the performance of rice through its effect on growth and development. However, the information on response of greengram to residual effects of rice crop establishment methods and direct as well as residual effects of nutrient management practices in rice-greengram cropping system is limited. Further the study of energetics, which is relatively a stable index unlike economics of production, assumes paramount importance in the present era of energy crisis. It is an approach to gauge, quantify and determine relationship between input and output to augment energy use efficiency and crop productivity.

Keeping these things in view the present experiment was conducted to study the energetics of greengram production in relation to residual effect of rice establishment methods and direct as well as residual effect of nutrient management practices in rice-greengram cropping system.

\section{Materials and methods}

A field experiment was conducted at the Instructional farm of Krishi Vigyan Kendra, Shyamakhunta, Mayurbhanj $\left(21^{\circ} 56^{\prime} \mathrm{N}, 86^{\circ} 46^{\prime} \mathrm{E}\right.$ and $50 \mathrm{~m}$ above mean sea level) under North Central Plateau Agro-climatic Zone of Odisha during rabi seasons of 2009-10 and 2010-11. The experimental soil was sandy clay loam in texture, pH 5.63, organic carbon $0.46 \%$, available N $221 \mathrm{~kg} \mathrm{ha}^{-1}$, available $\mathrm{P} 10.4 \mathrm{~kg} \mathrm{ha}^{-1}$ and available K 139.3 $\mathrm{kg} \mathrm{ha}^{-1}$. The design of the experiment was spilt plot in kharif and split-spilt plot during rabi with three replications each. The kharif treatments included three rice establishment methods viz., system of rice intensification (SRI), direct sowing of sprouted seeds by drum-seeder (DS) and conventional transplanting (CT) as main plot and three nutrient management practices viz. recommended dose of fertilizer i.e. $80 \mathrm{~kg} \mathrm{~N}, 40 \mathrm{~kg}$ $\mathrm{P}_{2} \mathrm{O}_{5}$ and $40 \mathrm{~kg} \mathrm{~K}_{2} \mathrm{O} \mathrm{ha}^{-1}$ (RDF), integrated nutrient management (INM) i.e.50\% of R.D.F. through inorganic fertilizers $+50 \%$ of R.D.F. through organic sources (based on nitrogen requirement) and organic management 
(OM) i.e. $100 \%$ of R.D.F. through organic sources (based on nitrogen requirement). The organic sources comprised of 50\% nitrogen requirement through FYM, 25\% through vermicompost and remaining $25 \%$ through neem oil cakes. The rabi treatments included residual effects of kharif treatments as well as direct effect of three nutrient management practices on greengram viz., $\mathrm{RDF}\left(20 \mathrm{~kg} \mathrm{~N}, 40 \mathrm{~kg} \mathrm{P}_{2} \mathrm{O}_{5}\right.$ and $\left.40 \mathrm{~kg} \mathrm{~K}_{2} \mathrm{O} \mathrm{ha}^{-1}\right), 50 \% \mathrm{RDF}+$ Biofertlizer (seed inoculation of Rhizobium and PSB @ $500 \mathrm{~g} \mathrm{ha}^{-1}$ each) and no fertilizer application. Randomization of treatments in kharif and rabi remained the same during both the years of experimentation.

During kharif, twenty five-day old rice 'Pratikshya' seedlings (two-three/hill) were transplanted at 20 $\mathrm{cm} \times 15 \mathrm{~cm}$ spacing in CT method and 12-day old were transplanted at $25 \mathrm{~cm} \times 25 \mathrm{~cm}$ spacing in SRI method (one seedling/hill), while pre-germinated seeds were sown by using a four-row paddy drum seeder in a puddled soil with rows of $20 \mathrm{~cm}$ apart. Water levels of $5 \mathrm{~cm}$ were maintained in CT and DS methods throughout the growing period while soil moisture saturation was maintained in SRI method. One-fourth of nitrogen and full dose of $\mathrm{P}$ and $\mathrm{K}$ were applied as basal and remaining nitrogen was top dressed twice i.e. half at active tillering stage and one-fourth at panicle initiation stage for all the treatments. The organic manures required to substitute the amount of $\mathrm{N}$ as per the treatments were calculated and incorporated immediately after layout of the experiment.

'PDM-54' was taken as the test cultivar for rabi experiment. Seeds were sown with a row spacing of 25 $\mathrm{cm} @ 25 \mathrm{~kg} \mathrm{ha}^{-1}$ after harvest of rice crop. Rhizobium and PSB cultures were inoculated @ $25 \mathrm{~g}$ each per kg of seed before sowing in the treatment $50 \% \mathrm{RDF}+$ Bio-fertilizer. All the chemical fertilisers were applied basally through urea, diammonium phosphate and muriate of potash. Plant to plant spacing was maintained at $10 \mathrm{~cm}$ by thinning the additional plants after 10 days of sowing. A light irrigation was provided at the time of flowering. For plant protection measures, monocrotophos @ $2.5 \mathrm{ml} /$ litre with 400 litres of water per ha was sprayed once in each year to control sucking pests as well as pod borers. The matured pods were plucked manually from the plants in net plot area for recording the economic yield plot-wise. The pods were sun dried for 3-4 days and threshed manually. The seed and haulm yield were recorded plot-wise after reduction of moisture content to $8 \%$. Energy input was calculated from sowing to harvest pertaining to each treatment. It was estimated in Mega Joule (MJ) ha ${ }^{-1}$ with reference to the standard values prescribed by Mittal et al. (1985). The standard energy coefficients for seed and straw were multiplied with their respective yields and summed up to obtain the energy output. Based on the energy equivalents of inputs and output, the energy indices such as energy ratio (energy output/energy input) and energy productivity (grain yield/energy input) were calculated as per Rafiee et al., 2010.

\subsection{Yield}

\section{Results and discussion}

The establishment methods of rice did not influence the yield of subsequent greengram crop (Table 1). However, application of sole organic nutrition (OM) and INM in rice being at par with each other recorded significantly higher seed and haulm yield of succeeding greengram over RDF. A perusal on pooled data revealed that the seed yield under residual effect of organic nutrition $\left(852 \mathrm{~kg} \mathrm{ha}^{-1}\right)$ was more by 10.1 and $20.5 \%$ over the residual effect of INM and RDF, respectively. Also, organic nutrition applied to kharif rice recorded the highest harvest index $(26.26 \%)$ during the second year only, which remained at par with INM and the latter recorded comparable harvest index with RDF. The favorable performance of residual effect of organics alone or in combination with inorganic fertilizers might be due to prolonged availability of nutrients in such treatments as compared to RDF only. Kumari and Reddy (2011) also reported higher yield of succeeding crop of groundnut with application of $100 \%$ nitrogen through FYM to preceding rice being comparable with supply of 50 per cent nitrogen each through FYM and chemical fertilizer, but significantly superior to $100 \%$ nitrogen through chemical fertilizer and non-supply of nitrogen to preceding crop of rice. As regards to application of direct treatments in greengram, $50 \% \mathrm{RDF}+\mathrm{BF}$ recorded the highest seed $\left(930 \mathrm{~kg} \mathrm{ha}^{-1}\right)$ and haulm yield $\left(2596 \mathrm{~kg} \mathrm{ha}^{-1}\right)$ with a yield advantage of 10.7 and $64.9 \%$ over RDF and no fertilizer application, respectively. Similar findings of higher yield of greengram due to application of biofertilizers have been reported by Panigrahi et al., 2012 and Math et al., 2012. Significantly lowest seed and haulm yield was recorded with no fertilizer during both the years. The yield increase under $50 \% \mathrm{RDF}+\mathrm{BF}$ might be not only due to $\mathrm{N}$ fixation and phosphate solubilization, but also due to release of growth promoting substances, control of plant pathogens and proliferation of beneficial organisms in the rhizosphere in this treatment. Solubilizers of inorganic phosphates in the soil (PSB) make them available to the crop and result in better yield (Charyulu et al. 1985). The poor performance of greengram under no fertilizer application suggested that the plants could not get the required quantity of nutrients matching its demand. However, both RDF and $50 \%$ RDF + BF being comparable to each other produced higher harvest index than no fertilizer which indicated that under optimal nutrient supply irrespective of source, the plants were equally effective in synthesis and translocation of photosynthates from source to sink. 


\subsection{Energetics}

The study (Table 2) revealed that residual effect of different crop establishment methods of rice did not influence the energetics of greengram crop significantly. However, variation was observed due to residual effect of nutrient management practices to rice and treatments applied directly to greengram. Application of RDF to greengram used the maximum energy $\left(4.65 \mathrm{MJ} \times 10^{3}\right)$ followed by $50 \% \mathrm{RDF}+\mathrm{BF}\left(3.76 \mathrm{MJ} \times 10^{3}\right)$ and the least energy was used by no fertilizer $\left(2.71 \mathrm{MJ} \times 10^{3}\right)$ for production of greengram. The residual effect of organic nutrition resulted in the highest energy output during both the years as well as in pooled data; but it remained statistically similar to INM on pooled basis. The lowest energy output was registered under residual effect of $\mathrm{RDF}$ to rice. The effect of treatments applied directly to greengram revealed that the highest energy output was obtained under $50 \%$ RDF + BF during both the years and based on pooled data. The lowest value of energy output was registered under no fertilizer treatment. The data on energy productivity showed that as per pooled analysis, residual effect of organic nutrition recorded significantly the highest value of energy productivity $\left(231.1 \mathrm{~kg} / \mathrm{MJ} \times 10^{3}\right)$, which was higher by $9.3 \%$ and $19.6 \%$ than those recorded from residual effect of INM and RDF, respectively. However, the latter two treatments as well as INM and OM recorded statistically comparable values of energy productivity during both the years. 50\% RDF $+\mathrm{BF}$ application to greengram recorded significantly the highest value of energy productivity $\left(247.3 \mathrm{~kg} / \mathrm{MJ} \times 10^{3}\right)$, which was 37 and $18.9 \%$ higher over those was obtained with RDF and no fertilizer application as per pooled data. Similar to the trend in energy output and energy productivity, the energy ratio was the highest due to the residual effect of organic nutrition, though it remained at par with the residual effect of INM during both the years. Also, residual effect of INM and RDF recorded statistically similar values during both the years. But as per pooled data, residual effect of organic nutrition recorded significantly the highest energy ratio (14.06), which was superior to all other treatments. The influence of treatments applied directly to greengram revealed that the highest energy ratio was computed from $50 \% \mathrm{RDF}+\mathrm{BF}$ and the least from no fertilizer irrespective of the year of study. The higher values of energy parameters exhibited by residual effect of organic nutrition and direct application of $50 \% \mathrm{RDF}+\mathrm{BF}$ to greengram were on account of higher seed and haulm yields and lower energy inputs under these treatments.

\section{Conclusion}

Thus it is concluded that application of either organic nutrition or INM to kharif rice followed by direct application of $50 \% \mathrm{RDF}$ along with biofertiliser seed treatment to greengram is more productive and energy efficient in North Central Plateau Zone of Odisha.

References

[1] P.B.B.N Charyulu, F. Fourcassie, A.K. Barbouche, L.R. Harisoa, A.M.N. Omar, P. Weinhard, R. Maric and Balandreau. Field inoculation of rice using in vitro selected bacterial and plant genotypes, Azospirillum III Genetics, Physiology and Ecology (W. Klingmuller, Ed: Springer Verlag, Berlin, 1985, 163-179)

[2] G.O.I. (2013). Agricultural Statistics at a Glance (Government of India, Ministry of Agriculture, Department of Agriculture and Cooperation, Directorate of Economics and Statistics, New Delhi, 2013)

[3] C.R. Kumari and S.D. Reddy, Sustainable nitrogen management in rice based cropping system. Indian Journal of Agricultural Research 45(2), 2011, 93-103.

[4] G. Math, A.G. Vijaykumar, C.D. Soragaon, S.M. Hiremath and P.Y. Kamannavar, Integrated nutrient management in urdbean. In: Extended Summaries of Third International Agronomy Congress, IARI, New Delhi, 2012, 484.

[5] V.K. Mittal, J.P. Mittal and K.C. Dhawan, Research digest on energy requirements in Agriculture sector (1971-82), ICAR/AICRP/ERAS/85 (1), Ludhiana, 1985, 159-163.

[6] OAS (2010-11). Odisha Agriculture Statistics (Directorate of Agriculture and Food Production, Govt. of Odisha, 2010-11)

[7] R.K. Panigrahi, A.K.B. Mohapatra and A.K. Padhi, Integrated nutrient management in rabi mungbean. In: Extended Summaries of Third International Agronomy Congress, IARI, New Delhi, 2012, 278-279.

[8] S. Rafiee., S.H. Mousavi Avval and A.Mohammadi, Modelling and sensitivity analysis of energy inputs for apple production in Iran. Energy 35(8), 2010, 3301-3306

Table 1. Effect of rice crop establishment and nutrient management practices in rice -greengram cropping on

\begin{tabular}{|c|c|c|c|c|c|c|c|c|c|}
\hline \multirow[t]{2}{*}{ Treatments } & \multicolumn{3}{|c|}{ Seed yield $\left(\mathrm{kg} \mathrm{ha}^{-1}\right)$} & \multicolumn{3}{|c|}{ Haulm yield $\left(\mathrm{kg} \mathrm{ha}^{-1}\right)$} & \multicolumn{3}{|c|}{ Harvest index $(\%)$} \\
\hline & $2009-10$ & $2010-11$ & Pooled & $2009-10$ & $2010-11$ & Pooled & $2009-10$ & $2010-11$ & Pooled \\
\hline \multicolumn{10}{|c|}{ Crop establishment methods in rice } \\
\hline SRI* & 736 & 821 & 779 & 2194 & 2324 & 2259 & 24.86 & 25.87 & 25.37 \\
\hline DS & 775 & 867 & 821 & 2287 & 2394 & 2341 & 25.12 & 26.35 & 25.74 \\
\hline $\mathrm{CT}$ & 694 & 774 & 734 & 2077 & 2240 & 2159 & 24.84 & 25.47 & 25.16 \\
\hline $\mathrm{SE} \mathrm{m}( \pm)$ & 21.26 & 28.43 & 17.75 & 56.73 & 75.71 & 47.30 & 0.137 & 0.226 & 0.132 \\
\hline $\mathrm{CD}(0.05)$ & NS & NS & NS & NS & NS & NS & NS & NS & NS \\
\hline \multicolumn{10}{|c|}{ Nutrient management in rice } \\
\hline $\mathrm{RDF}^{*}$ & 668 & 746 & 707 & 2034 & 2158 & 2096 & 24.57 & 25.56 & 25.07 \\
\hline OM & 802 & 902 & 852 & 2342 & 2495 & 2419 & 25.26 & 26.26 & 25.76 \\
\hline INM & 734 & 814 & 774 & 2182 & 2305 & 2244 & 24.99 & 25.88 & 25.44 \\
\hline
\end{tabular}


Energetics of Greengram (Vigna radiata L.) Production as Affected by Residual Effect of ....

\begin{tabular}{|c|c|c|c|c|c|c|c|c|c|}
\hline $\operatorname{Sem}( \pm)$ & 29.31 & 31.80 & 21.62 & 71.13 & 80.59 & 53.75 & 0.244 & 0.173 & 0.149 \\
\hline $\mathrm{CD}(0.05)$ & 90 & 98 & 63 & 219 & 248 & 157 & NS & 0.53 & NS \\
\hline \multicolumn{10}{|c|}{ Nutrient management in greengram } \\
\hline $\mathrm{RDF}^{* *}$ & 791 & 888 & 840 & 2322 & 2474 & 2398 & 25.38 & 26.34 & 25.86 \\
\hline $50 \% \mathrm{RDF}+\mathrm{BF}$ & 879 & 981 & 930 & 2519 & 2673 & 2596 & 25.80 & 26.76 & 26.28 \\
\hline No fertiliser & 534 & 593 & 564 & 1716 & 1811 & 1764 & 23.65 & 24.60 & 24.13 \\
\hline $\mathrm{SE} \mathrm{m}( \pm)$ & 23.32 & 25.03 & 17.11 & 59.37 & 60.98 & 42.55 & 0.360 & 0.234 & 0.215 \\
\hline $\mathrm{CD}(0.05)$ & 67 & 72 & 48 & 170 & 175 & 120 & 1.03 & 0.67 & 0.61 \\
\hline
\end{tabular}

$* \mathrm{SRI}=$ System of rice intensification; $\mathrm{DS}=$ Drum seeding; $\mathrm{CT}=$ Conventional transplanting; $\mathrm{RDF} *$ (Recommended dose of fertilizer) $=80 \mathrm{~kg} \mathrm{~N}, 40 \mathrm{~kg} \mathrm{P}_{2} \mathrm{O}_{5}$ and $40 \mathrm{~kg} \mathrm{~K}_{2} \mathrm{O} \mathrm{ha}^{-1}$; OM = Organic management $(50 \%$ $\mathrm{N}$ through FYM $+25 \% \mathrm{~N}$ through vermicompost $+25 \% \mathrm{~N}$ through neem oil cake); INM = Integrated nutrient

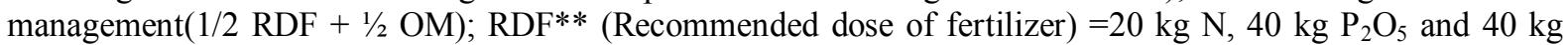
$\mathrm{K}_{2} \mathrm{O} \mathrm{ha}^{-1} ; \mathrm{BF}=$ Bio-fertilizers (Rhizobium and PSB seed inoculation)

Table 2. Effect of rice crop establishment and nutrient management practices in rice -greengramcropping

\begin{tabular}{|c|c|c|c|c|c|c|c|c|c|c|}
\hline \multirow[t]{2}{*}{ Treatments } & \multirow{2}{*}{$\begin{array}{c}\text { Energy } \\
\text { input } \\
(\mathrm{MJ} x \\
\left.10^{3}\right)\end{array}$} & \multicolumn{3}{|c|}{$\begin{array}{l}\text { Energy output } \\
\left(\mathrm{MJ} \times 10^{3}\right)\end{array}$} & \multicolumn{3}{|c|}{$\begin{array}{l}\text { Energy productivity }(\mathrm{kg} / \mathrm{MJ} \mathrm{x} \\
\left.110^{3}\right)\end{array}$} & \multicolumn{3}{|c|}{ Energy ratio } \\
\hline & & $\begin{array}{c}2009- \\
10\end{array}$ & 2010-11 & Pooled & $2009-10$ & $\begin{array}{c}2010- \\
11\end{array}$ & Pooled & $\begin{array}{c}2009- \\
10\end{array}$ & $\begin{array}{c}2010- \\
11\end{array}$ & Pooled \\
\hline \multicolumn{11}{|c|}{ Crop establishment methods in rice } \\
\hline SRI* & 3.71 & 45.8 & 49.6 & 47.7 & 200.7 & 223.8 & 212.3 & 12.56 & 13.58 & 13.07 \\
\hline DS & 3.71 & 48.0 & 51.6 & 49.8 & 210.9 & 235.6 & 223.2 & 13.11 & 14.09 & 13.60 \\
\hline $\mathrm{CT}$ & 3.71 & 43.3 & 47.3 & 45.3 & 189.4 & 211.2 & 200.3 & 11.88 & 12.99 & 12.44 \\
\hline $\mathrm{SE} \mathrm{m}( \pm)$ & - & 1.23 & 1.64 & 1.02 & 5.13 & 6.53 & 4.15 & 0.311 & 0.380 & 0.245 \\
\hline $\mathrm{CD}(0.05)$ & - & NS & NS & NS & NS & NS & NS & NS & NS & NS \\
\hline \multicolumn{11}{|c|}{ Nutrient management in rice } \\
\hline $\mathrm{RDF}^{*}$ & 3.71 & 42.1 & 45.6 & 43.9 & 182.7 & 203.9 & 193.3 & 11.57 & 12.52 & 12.04 \\
\hline $\mathrm{OM}$ & 3.71 & 49.3 & 53.7 & 51.5 & 217.7 & 244.5 & 231.1 & 13.46 & 14.65 & 14.06 \\
\hline INM & 3.71 & 45.6 & 49.2 & 47.4 & 200.6 & 222.2 & 211.4 & 12.53 & 13.49 & 13.01 \\
\hline $\mathrm{Se} \mathrm{m}( \pm)$ & - & 1.60 & 1.79 & 1.20 & 7.98 & 8.53 & 5.84 & 0.427 & 0.479 & 0.321 \\
\hline $\mathrm{CD}(0.05)$ & - & 4.9 & 5.5 & 3.5 & 24.6 & 26.3 & 17.0 & 1.32 & 1.48 & 0.94 \\
\hline \multicolumn{11}{|c|}{ Nutrient management in greengram } \\
\hline $\mathrm{RDF}^{* *}$ & 4.65 & 48.8 & 53.1 & 51.0 & 170.1 & 190.9 & 180.5 & 10.50 & 11.42 & 10.96 \\
\hline $50 \% \mathrm{RDF}+$ & & & & & & & & & & \\
\hline $\mathrm{BF}$ & 3.76 & 53.5 & 57.9 & 55.7 & 233.9 & 260.8 & 247.3 & 14.22 & 15.41 & 14.81 \\
\hline No fertiliser & 2.71 & 34.8 & 37.5 & 36.1 & 197.0 & 219.0 & 208.0 & 12.84 & 13.83 & 13.33 \\
\hline $\mathrm{SE} \mathrm{m}( \pm)$ & - & 1.25 & 1.36 & 0.92 & 6.28 & 7.02 & 4.71 & 0.334 & 0.383 & 0.254 \\
\hline $\mathrm{CD}(0.05)$ & - & 3.6 & 3.9 & 2.6 & 18.0 & 20.1 & 13.3 & 0.96 & 1.10 & 0.72 \\
\hline
\end{tabular}

$* \mathrm{SRI}=$ System of rice intensification; DS = Drum seeding; CT $=$ Conventional transplanting; RDF* (Recommended dose of fertilizer) $=80 \mathrm{~kg} \mathrm{~N}, 40 \mathrm{~kg} \mathrm{P}_{2} \mathrm{O}_{5}$ and $40 \mathrm{~kg} \mathrm{~K}_{2} \mathrm{O} \mathrm{ha}^{-1}$; OM = Organic management $(50 \%$ $\mathrm{N}$ through FYM $+25 \% \mathrm{~N}$ through vermicompost $+25 \% \mathrm{~N}$ through neem oil cake); INM = Integrated nutrient

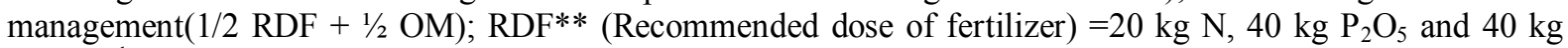
$\mathrm{K}_{2} \mathrm{O} \mathrm{ha}^{-1} ; \mathrm{BF}=$ Bio-fertilizers (Rhizobium and PSB seed inoculation) 